\title{
Dziennik malarski jako fenomen artystyczno-psychologicznego wyrazu i oddziaływania
}

\section{Spontaniczność psychofizjologiczna}

Umyst jest aktywny przez całą dobę, również wtedy, gdy ciało jest pogrążone we śnie (Stahl, 2008; LeDoux, 2017). Cokolwiek przychodzi człowiekowi na myśl, jeśli nie jest celowe i nie wynika z wykonywania konkretnego zadania, jest przejawem aktywności umysłowej zasadzającej się na aktywności mózgowej, która jest catkowicie spontaniczna (Stahl, 2008; LeDoux, 2017). Mózg pracuje nieprzerwanie, a chwile wytchnienia vide zmiany dynamiki jego aktywności pojawiają się wtedy, gdy doświadcza się wyraźnego poczucia bezpieczeństwa. Mózg, naturalną koleją rzeczy, szacuje zagrożenie w ciągłym percypowaniu otoczenia, ale również w reakcji na bodźce wewnętrzne, takie jak sny, dolegliwości ciała, jego własne produkty w postaci myśli - zarówno zwerbalizowanych, jak i obrazów, odczuć, dźwięków, bliżej nieokreślonych doznań wewnętrznych (Stahl, 2008; LeDoux, 2017).

Reagowanie, odczuwanie, myślenie nie powstają tylko na podstawie bodźców zewnętrznych. Pełnoprawną przestrzenią, która konfiguruje się z bodźcami zewnętrznymi w procesie percepcji otoczenia, jest przestrzeń bodźców wewnętrznych, tzw. od-trzewnych (LeDoux, 2017). Mózg nieustająco otrzymuje sygnały z ciała, wśród których każdy z organów ma własne miejsce wynikające z przydzielonej ewolucyjnie wiązki nerwów obwodowych, które komunikują się z nim przez nerw błędny (Longstaff, 2009). Składnikiem myśli jest więc również odbiór własnej cielesności - w dużej mierze nieświadomy, dalece zautomatyzowany, nieprzedzierający się do świadomości, jeśli nie przekroczy pewnego progu pobudzenia, za którym zaczyna się choćby doznanie bólu, na przykład brzucha czy głowy (LeDoux, 2017). 


\section{Narracja wewnętrzna, uwaga i świadomość}

W kontekście, którym jest częściowo nieświadome, a częściowo świadome tło tworzone przez bodźce od-trzewne, rozgrywają się spontaniczne myśli w postaci obrazów i/lub werbalizacji, tzw. wewnętrznej narracji (Beck, 2011; Kahneman, 2011; Kabat-Zinn, 2018). Nie podlegając strukturze konkretnego zadania, mają one charakter przypadkowych, skokowo jak czkawka odbijających się treści. Za myślami podąża uwaga - jedna z podstawowych funkcji poznawczych (Nęcka, Orzechowski, Szymura, 2008; Jaśkowski, 2009; Beck, 2011; Kahneman, 2011; Kabat-Zinn, 2018). Uwaga zanurzona w myślach wędruje razem z nimi tam, gdzie poniosą, a więc od przypadku do przypadku, od Sasa do Lasa, z obecnej chwili do przeszłości, a stamtąd w bardziej lub mniej odległą przyszłość, zatrzymując się po drodze w teraźniejszości lub nie - przeskoki mogą być zarówno odległe, jak i gwałtowne (Beck, 2011; Kahneman, 2011; Kabat-Zinn, 2018).

Jeśli myśli się o tym, co było, to uwaga podąża w przeszłość, a więc w zdarzenia, które minęły i nie ma się już na nie wpływu. Jeśli człowiek zastanawia się nad tym, czego jeszcze nie ma lub oczekuje/wyczekuje tego, co będzie, to uwaga krąży w przyszłości, a więc w zdarzeniach, których de facto nie ma, nie wiadomo, czy kiedykolwiek nastąpią i w związku z tym wpływ na nie jest tylko częściowy, zwykle niewielki - o tyle, o ile można w świetle istniejących faktów coś trafnie przewidywać i na coś skutecznie się przygotowywać, na przykład jak się ubrać, co powiedzieć, co zrobić itp. (Beck, 2011; Kahneman, 2011; William, Penman, 2014; Kabat-Zinn, 2018). Uwaga zanurzona w przyszłości jest tam w istocie rzeczy utrzymywana produkcją umysłowych wariantów nieistniejących zdarzeń!

Za uwagą podąża świadomość - im dalej w przeszłość lub w przyszłość, tym dalej od teraźniejszości (Kabat-Zinn, 2018). „Zaobserwuj, jak myśli odrywają naszą świadomość od chwili obecnej, bez względu na okoliczności. Zwróć uwagę, jak długo w ciągu dnia myślisz o przeszłości albo przyszłości. Podsumowanie może okazać się szokujące" - pisze w swojej książce Jon Kabat-Zin (2018: 71), profesor medycyny z Uniwersytetu Massachusetts, założyciel Kliniki Redukcji Stresu i Centrum Badań nad Zastosowaniem Uważności w Opiece Zdrowotnej i Społeczeństwie. Przez kilka ostatnich dziesięcioleci tworzenia, wdrażania i badania technik uważności (Mindfulness) w środowiskach klinicznych wśród chorych na depresję, zaburzenia lękowe i inne problemy psychiczne na gruncie medycyny i psychologii nie ma już wątpliwości, że uważność jest, obok rozwijanych od lat siedemdziesiątych XX wieku technik terapii poznawczo-behawioralnej, najbardziej skutecznym obszarem leczniczego oddziaływania w problemach psychicznych (Teasdale, Williams, Segal, 2014; Kabat-Zinn, 2018). Jest to tym ważniejsze, że problemy 
psychiczne może mieć i miewa każdy człowiek, jeśli tylko znajdzie się w okolicznościach sprzyjających destabilizacji życiowej lub nawet tylko zachwianiu własnego wewnętrznego poczucia bezpieczeństwa (Carlson, 2005; Hammen, 2006). Takimi okolicznościami nie muszą być tylko zdarzenia losowe, jak nagła choroba, porzucenie, ograniczenie sprawności, śmierć kogoś bliskiego itp. Mogą nimi być również myśli - skutek spontanicznej aktywności mózgowej, produkty nieustająco aktywnego mózgu (Goleman, Lama, 2004; Beck, 2011; Kabat-Zinn, 2018). Myśli mogą mieć postać zróżnicowaną i dodatkowo świadomą lub nieświadomą. Nawet sny - jako niekontrolowany zwyczajowo wolą i świadomością przejaw spontanicznej aktywności mózgowej - mogą wpływać na doznania emocjonalne i stan ogólnego samopoczucia (LeDoux, 2017). Myśli mogą być zarówno chciane, jak i niechciane, przyjemne lub frustrujące, wpływające dodatnio na samopoczucie lub obniżające je, czasami do poziomu stanu emocjonalnego na tyle dojmującego, że ograniczają poczucie własnej sprawczości ${ }^{1}$ i kontroli; prowadzą do ogólnego negatywizmu, czasami również do poczucia braku sensu i nadziei (Padesky, Greenberger, 2004; Hammen, 2006; Beck, 2011).

Jeśli zaczniesz zwracać uwagę, gdzie w każdej kolejnej chwili dnia znajduje się twój umysł [...], być może przekonasz się, ile czasu i energii wydatkujesz na Ignięcie do wspomnień, sny na jawie i żal za tym, co minęło. Pewnie odkryjesz również, że tyle samo albo jeszcze więcej energii poświęcasz przewidywaniu, planowaniu, fantazjowaniu na temat przyszłości i martwieniu się o nią (Kabat-Zinn, 2018: 73).

Rzecz w tym, że obniżony nastrój i poczucie wewnętrznego ograniczenia zawierają się w treściach tych myśli, a więc w rzeczywistości, która nie musi być rzeczywistością faktu, ale z pewnością może być rzeczywistością interpretacji faktu, a to już duża - psychologicznie rzecz ujmując - różnica.

1 Poczucie własnej sprawczości, zwane również umiejscowieniem kontroli (locus of control), to jedno z podstawowych pojęć psychologicznych, wskazujące na indywidualny poziom poczucia wpływu na własne życie i możliwości. Rozróżnia się tak zwane wewnętrzne i zewnętrzne umiejscowienie kontroli. Pierwsze wiąże się z silnym poczuciem wpływu na własne możliwości i życie, a więc wysoką własną sprawczością, a drugie odwrotnie - z niskim poczuciem własnej sprawczości w obliczu czynników zewnętrznych, na przykład sił wyższych, nagłych zdarzeń losowych, autorytarnej zależności od kogoś. Im silniejsze przekonania dotyczące istnienia fatum, tym niższe poczucie własnej sprawczości wynikające z dominującego zewnętrznego umiejscowienia kontroli (Reber, Reber, 2008). 


\section{Dwie rzeczywistości}

Treści myśli wskazujące na istnienie czegoś, co istnieje w rzeczywistości zewnętrznej (np. „mam własny dom”), wpływają na nastrój inaczej niż myśli, których treść wskazuje na rzeczywistość subiektywną (np. „mój dom jest brzydki i beznadziejny”). Tym bardziej, gdy myśl dotyczy przyszłości, a więc faktów, których nie ma - wtedy jest z pewnością jedynie rzeczywistością interpretacyjnej fikcji. Przykładowo: gdy myśli się, biorąc pod uwagę fakt obiektywny, na przykład „zbliża się wystawa moich prac", to wskazuje się w takiej myśli na to, co rzeczywiście ma się wydarzyć, jeśli jest zaplanowane. Jeśli jednak myśli się, że wystawa będzie fiaskiem, bo nigdy nie będzie się dobrym artystą, to jest to już treść nie tylko wskazująca na przyszłość, czyli nie na fakt istniejący, ale również na wartość ujemną tego, co jeszcze się nie wydarzyło, a w myśli zakłada się, że się wydarzy i to w określony sposób (negatywny). Pierwsza myśl nie ma wartości obniżającej nastrój, ale może taką mieć, jeśli jest sprzęgnięta z drugą myślą, bo ta, sama w sobie, niesie już ładunek ujemnego, subiektywnego wartościowania. Kluczowe jest więc rozstrzygnięcie między rzeczywistością obiektywną vide faktem mającym miejsce w danym momencie, faktem dokonanym w przeszłości, faktem zaplanowanym, który wiadomo, że będzie miał miejsce a rzeczywistością subiektywną, wynikającą z interpretacyjnej narracji wobec rzeczywistości obiektywnej.

\section{Bezrozumność i życie na „automatycznym pilocie”}

Uświadamiając sobie, że ciągły potok myśli to umysłowe przejawy spontanicznej aktywności mózgowej, a aktywność ta ma swoje konkretne fizjologiczne aspekty (choćby takie jak elektromagnetyczność wraz z jej tempem, siłą i częstotliwością wyładowań potocznie zwanych impulsami mózgowymi, lub neuroprzekaźnictwo wraz z jakością oraz ilością produkcji neuroprzekaźników), nieuniknione staje się pytanie o to, jaki jest związek między fizjologią a myśleniem w aspekcie ich spontanicznej współaktywności (Stahl, 2008; Kahneman, 2011; LeDoux, 2017). Otóż jest to zależność, w której oba te czynniki wzajemnie na siebie wpływają, tworząc błędne koło. W tym błędnym kole kręci się uwaga, a wraz z nią świadomość własnego Ja danej osoby. Dzieje się to automatycznie i na tyle szybko, że trudno czasami przyjąć do wiadomości, że wiele myśli jest bezwartościowych, zbędnych, destrukcyjnych wobec rzeczywistych możliwości człowieka i co najważniejsze - całkowicie przypadkowych, subiektywnych i nielogicznych, po prostu bezrozumnych (Kahneman, 2011; LeDoux, 2017). Dlatego w ujęciu Mindfulness ważna 
jest nie tylko świadomość dotycząca prawdziwej natury własnych myśli, ale również świadomość życia na tak zwanym automatycznym pilocie (Teasdale, William, Segal, 2014; Kabat-Zinn, 2018). Chodzi o tak daleko idące przywiązanie do własnych myśli i głębokie pogrążenie się we wszystkim, co niosą w swojej silnie spolaryzowanej na przeszłość i przyszłość treści filtrującej otoczenie, że jest to w rezultacie życie bez uważnego kontaktu z teraźniejszością - właściwie poza nią (Teasdale, William, Segal, 2014; Kabat-Zinn, 2018).

"Bycie na automatycznym pilocie” to stan na tyle silnego przywiązania do własnych regularnie, ale przypadkowo, spontanicznie pojawiających się każdego dnia myśli, że trudno nie tworzyć z nich własnego Ja osobowego. W rezultacie każdy człowiek może powiedzieć coś o sobie, posiłkując się tym, jakich treści w swoich myślach najczęściej doświadcza. Stąd nietrudno jest subiektywnie określić siebie jako na przykład melancholijnego, ostrożnego, rozważnego, nieufnego czy roztargnionego. W świecie spontanicznej interpretacji zdarzeń, które były, i/lub zdarzeń, których nie ma, wszystko może się wydarzyć. Ludzka spontaniczna, wewnętrzna narracja jest krainą wzlotów i upadków o tempie i sile nieporównanie większej niż w życiowej rutynie - tym bardziej, gdy zdamy sobie sprawę z faktu, że ten stan, jeśli nie jest ustrukturyzowany jakimś konkretnym zadaniem do wykonania, jest zwykłym stanem naturalnej dla człowieka bezrozumności. To w tym spontanicznym stanie swobodnie wskakujące i wyskakujące myśli i obrazy nie muszą mieć żadnej spójności i nie trzymają się żadnych reguł, co zresztą może mieć wyraz nie tylko w zdziwieniu człowieka, gdy doświadczy konkretnej treści, ale również w pytaniu o to, dlaczego ma takie, a nie inne myśli i częstokroć również mimo rozmaitych prób pozbycia się ich.

\section{Bezrozumność a ocenianie/wartościowanie i mózg}

Wartościowanie to często tylko powierzchnia narracyjnej spontaniczności/bezrozumności, pod którą znajdują się złożone schematy poznawcze, takie jak przekonania pośredniczące ${ }^{2}$ lub przekonania kluczowe ${ }^{3}$, ale już samo wartościowanie

2 Myśli albo przekonania pośredniczące to pojęcie z terminologii podejścia psychoterapeutycznego, tak zwanej terapii poznawczo-behawioralnej. Z jednym przekonaniem pośredniczącym może wiązać się wiele różnych spontanicznych myśli oceniających. Przekonanie pośredniczące w swojej treści wskazuje przede wszystkim na określoną postawę (nastawienie), wynikającą z założeń wobec siebie, świata, ludzi oraz zasady postępowania, na przykład „Przegrana jest czymś najgorszym, co może się wydarzyć" lub „Jeśli przegrywam, to jestem do niczego i nigdy nie będę tym, kim chcę być" (Padesky, Greenberger, 2004; Beck, 2011).

3 Myśli albo przekonania kluczowe to to samo co przekonania pośredniczące, z tą różnicą, że zawsze ich treść wskazuje na fatum, obejmując w istocie całe życie i przede wszystkim przyszłość, na przykład „Jestem beztalenciem, które nigdy do niczego nie dojdzie" lub „CO ja tu robię - przecież zawsze jestem gorszy od innych i nigdy się nie przebije" (Padesky, Greenberger, 2004; Beck, 2011). 
znacząco dynamizuje nastrój i wpływa na funkcjonowanie poznawczo-behawioralne ${ }^{4}$ (Padesky, Greenberger, 2004; Beck, 2011). Ocenianie zdarzeń, osób, siebie samego poprzez na przykład przymiotnikowanie może zarówno poprawiać nastrój, jak i obniżać go - zależnie od siły i znaczenia produkowanej treści. Można myśleć o czymś/kimś, że jest jakiś sam w sobie, ale można też myśleć, że jest jakiś w porównaniu do czegoś/kogoś. Przykładowo: myślenie o czyimś malarstwie może mieć formę stwierdzeń: to złe, a to dobre ${ }^{5}$ malarstwo; to zły, a to dobry artysta. Pomijając fakt, że opozycja złe - dobre może oznaczać tylko tyle, co podoba mi się - nie podoba mi się i w związku z tym jest skrajnie subiektywnym widzeniem rzeczywistości, to dodatkowo drugie stwierdzenie nie celuje jak pierwsze tylko w wytwór artysty, ale już w niego samego vide w konkretną osobę. Gdy ktoś mówi, że ten artysta jest zły ${ }^{6}$, to dotyka czegoś więcej niż tylko jego twórczości. Gdy artysta sam o sobie myśli, że jest zły, to wartościuje swoje Ja, choć przecież taka impulsywna ocena może wyłonić się tylko pod wpływem chwili i jednego obrazu lub wycinka twórczości. Tego typu generalizacje mogą być niebezpieczne psychicznie, bo są zniekształceniami poznawczymi w formie interpretacji rzeczywistości, a nie rzeczywistością (Padesky, Greenberger, 2004; Beck, 2011).

W ocenianiu jest jeszcze porównywanie. Można więc myśleć: „Moje malarstwo jest lepsze/gorsze od tamtego malarstwa”; „Ja jestem lepszy/gorszy od tamtego artysty”. Porównując się, zawsze można znaleźć kogoś, kogo da się wartościować na swoją korzyść lub niekorzyść. Wartościowanie ujemne obniża nastrój, a dodatnie poprawia (jeśli nie jest się na tyle negatywistycznym, że przyjmuje się je, nie dewaluując dodatniego wartościowania).

Różne czynniki mogą mniej lub bardziej sprzyjać skłonności do narracyjnego wartościowania, na przykład wychowanie (trening społeczny ${ }^{7}$ ), większe niż zwykle pobudzenie emocjonalne (nasilony afekt ${ }^{8}$ ), gorszy dzień, pogoda, wyraźnie dające się zauważyć dolegliwości fizyczne, choroba itp. (Beck, 2011; Damasio, 2018) Dodatkowo wartościowanie ujemne nie musi dotyczyć własnego Ja osobowego,

4 Odczuwanie i myślenie prowadzą do reagowania między innymi wewnętrzną awersją, a następnie do zachowania, na przykład unikającego (Beck, 2012).

5 Czarno-białe sądy o sobie, świecie, ludziach są charakterystycznym symptomem związanym z podwyższonym napięciem psychofizjologicznym i impulsywnością (Hammen, 2006; Kahneman, 2011).

6 Uproszczenia i generalizacje - jw.

7 Czarno-białe sądy, uproszczenia, generalizacje i silna potrzeba wewnętrzna oceniania w tych kategoriach są sprzężone z socjalizacją zdominowaną przez niepartnerskie, najczęściej autorytarne zamiast autorytatywne formy komunikacji oraz relacji interpersonalnych (Kahneman, 2011).

8 Afekt to jedno z podstawowych pojęć psychologicznych na gruncie psychofizjologii, odnoszące się do siły, częstotliwości i tempa reagowania emocjonalnego, na przykład im większy afekt u danej osoby, tym silniejsze jej reakcje emocjonalne w sytuacjach, w których wartość stymulacyjna bodźców jest słaba, vide tym łatwiej, szybciej i częściej pobudza się emocjonalnie, na przykład w kierunku złości przez irytację w reagowaniu na otoczenie (Damasio, 2018). 
by również obniżało nastrój. Rzecz w tym, że narracja wartościująca nie tworzy rzeczywistości per se, ale rzeczywistość wewnętrzną osoby konstruującej narrację, a to czasami kolosalna różnica. Istotny jest tutaj indywidualny poziom wyjściowy człowieka w jego psychofizjologicznym pobudzeniu', które jest tłem dla codziennej percepcji i może bardziej lub mniej „zaprawiać” narrację wewnętrzną rozmaitymi zniekształceniami poznawczymi (Kalat, 2006; LeDoux, 2017; Damasio, 2018). To pobudzenie jest osobniczym, zwyczajowym stanem gotowości psychofizjologicznej (psychiczne nastawienie, fizyczne parametry pobudzenia mięśniowo-kostnego) do działania, powstającym jako rezultat najczęściej oddziałujących na organizm bodźców z otoczenia (Kalat, 2006; LeDoux, 2017; Damasio, 2018). Okres rozwojowy, tj. do około 20., a dla mózgu do około 25. roku życia, jest kluczowy dla ukonstytuowania się ${ }^{10} \mathrm{~W}$ dorosłym układzie nerwowym gotowości do przetwarzania rozmaitych bodźców i reagowania na nie (Kalat, 2006; LeDoux, 2017; Damasio, 2018). Najważniejszymi mózgowymi strukturami w tym procesie są struktury korowe czołowe, tak zwana kora przednia: przyśrodkowa kora czołowa, kora nadoczodołowa, kora przednia zakrętu obręczy oraz struktury podkorowe, takie jak ciało migdałowate, wzgórze, hipokamp i istota szara okołowodociągowa (LeDoux, 2017). To w obrębie tych struktur rozgrywa się walka między pobudzeniem a hamowaniem i tym, co należy pamiętać, a czego nie trzeba, by reagować w dominującym poczuciu zagrożenia lub bezpieczeństwa na codzienność (LeDoux, 2017). Innymi słowy, to, czy ktoś w warunkach braku rzeczywistego zagrożenia, na przykład będąc bezpiecznym w domu i robiąc to, na co ma ochotę, będzie spontanicznie produkował więcej myśli negatywistycznych niż nienegatywistycznych, zależy w największym stopniu od jego treningu życiowego, którego doświadczyt, bo trening ten wygenerowat określony sposób elektromagnetycznego i neurochemicznego reagowania sieci neuronalnych połączeń pomiędzy wymienionymi strukturami mózgowymi.

9 Zwyczajowej dla danej osoby mobilizacji psychofizjologicznej do działania w rutynowych czynnościach. Im wyższa jest tego typu mobilizacja, tym silniejsze napięcie jej towarzyszące (Cozolino, 2004; Hammen, 2006; Stahl, 2009; LeDoux, 2017).

10 Badania Josepha LeDoux (2017) na przestrzeni ostatnich kilkudziesięciu lat bardzo dokładnie wykazały, jak sieci neuronalne utrwalają wzorce pobudzenia i hamowania w strukturach związanych z afektem, reakcjami obronnymi, emocjami i zapamiętywaniem kontekstu w odpowiedzi na bodźce zewnętrzne. Przykładowo: osoba silnie stymulowana oceną negatywną z otoczenia może doświadczać silnego pobudzenia nerwowego w każdej sytuacji, w której kontekstem dla jej reakcji jest ocenianie. Konfiguracja aktywności neuronalnej pobudzeniowej z hamującą może zatem zostać utrwalona mniej lub bardziej korzystnie dla danej osoby, skutkując między innymi większym lub mniejszym kosztem energetycznym jej reagowania w określonym, istotnym dla tej osoby, w świetle jej historii życiowej, kontekście. 


\section{Automatyczne myśli oceniające i błędne koło nastroju}

Osoba, która w rezultacie swoich doświadczeń życiowych jest wystymulowana do reagowania częściej w poczuciu zagrożenia niż w poczuciu bezpieczeństwa, może bardzo wyraźnie doświadczać w swojej codzienności skutków takiego bilansu stymulacyjnego w postaci „dopadających ją” bez powodu nagłych automatycznych myśli ${ }^{11}$, których treść sprowadza się do oceniania, taksowania, szybkiego rozsądzania wszystkiego, o czym pomyśli zarówno w odniesieniu do przeszłości, jak i przyszłości, i zarówno w odniesieniu do ludzi w ogóle, jak i konkretnych osób, w tym siebie (Hammen, 2006; Beck, 2011). Te nagłe automatyczne myśli absorbują uwagę na tyle, że granica między rzeczywistością obiektywną (faktu) a narracją interpretacyjną (subiektywnym wartościowaniem) zostaje zatarta (Hammen, 2006; Beck, 2011). Ja osobowe zostaje nasycone treściami interpretacyjnymi zamiast rzeczywistymi - stąd między innymi możliwe są takie skutki jak zdziwienie i niedowierzanie w reakcji na rzeczywisty bieg zdarzeń, czasami wyrażane w treści: „To niemożliwe, żeby było dobrze” lub „Co z tego, że teraz coś mi się udało, to tylko chwila przecież i tak nic dobrego już mnie nie czeka”, „To jest złe”, „Beznadziejne”, „Jestem do niczego”, „Nigdy mi się to nie uda, wszyscy są przeciwko mnie”, „Ludzie są podli”, „Zawsze tylko pod górę”, „Życie to mordęga” itp.

Ten typ myślenia w odniesieniu do własnej twórczości będzie u artysty pełnit tę samą funkcję co u każdego innego człowieka, a mianowicie ciągłego nieintencjonalnego, automatycznego utrzymywania wewnętrznego poczucia dyskomfortu, na przykład zagrożenia, smutku, złości, irytacji, niechęci, wrogości - po prostu frustracji psychofizjologicznej zdominowanej przez niepokój i ogólną awersję psychiczną. W życiu artysty doświadczającego ciągłego poziomu frustracji wewnętrznej wena twórcza może kończyć się za każdym razem, gdy zaobserwuje on/ona, że danego dnia nie może malować, choć przyczyną może być wiele różnych rzeczy, na przykład zwykłe zmęczenie lub brak pomysłów wynikający z powtarzalności treści zasilającej zasoby umystowe danej osoby.

Każda chwila niedyspozycji może być interpretowana w krzywym zwierciadle spontanicznej, nawykowej narracji wartościującej ujemnie. Jak łatwo się domyślić, taki stan rzeczy tylko pogarsza kondycję psychofizjologiczną człowieka i jest bardziej kosztowny dla organizmu niż sytuacja, w której go nie ma. Regularnie

11 Nagłe automatyczne myśli (NAM) to pojęcie z terminologii podejścia psychoterapeutycznego, tak zwanej terapii poznawczo-behawioralnej, wskazujące na materiał poznawczy osoby, przejawiający się na samej powierzchni struktury poznawczej i najbardziej powiązany ze spontanicznymi myślami, na przykład „,Jestem złym artystą, ,"Ludzie są wstrętni”, ,'Świat jest obrzydliwy”. 
utrzymywany negatywistyczną narracją nadmiar tak zwanych hormonów stresu (glikokortykosteroidów ${ }^{12}$ ) i niedobór tych, które redukują poczucie zagrożenia ${ }^{13}$ (serotoniny, endorfiny, oksytocyny i innych) utrwala w organizmie nierównowage neurochemiczną, prowadząc jednocześnie do faktycznych ograniczeń poznawczych w zakresie pamięci, wyobraźni, motywacji do działania, a następnie również do twórczej niemocy (Stahl, 2008; Longstaff, 2009; LeDoux, 2017). Dodatkowo luka czasoprzestrzenna powstająca w chwilowej artystycznej niemocy, jeśli zostaje wypełniona negatywistyczną narracją wewnętrzną, to siłą rzeczy dołącza do sumy wcześniejszych ujemnych osobistych doświadczeń psychicznych, wzmacniając ich siłę oddziaływania i napędzając dodatkowo tę machinę negatywizmu. W ten sposób nie tylko kształtują się nawyki myślenia, ale również utrwalają się ich skutki, które sprzyjają kolejnym sytuacjom utrwalającym wcześniejsze itd. Powstaje błędne koło negatywistycznej, bezrozumnej narracji spontanicznej. Im szybciej kręci się takie koło, tym silniej przywiera do niego uwaga, a wraz z nią Ja osobowe. Nim człowiek zdąży się obejrzeć, już żyje w poczuciu, że jest beznadziejny, a jego życie to wieczna walka o przetrwanie, bo wszędzie jest „pod górkę” i tak naprawdę, to choćby nie wiadomo, jak się starał - zawsze będzie źle lub byle jak.

Wyjście z tego błędnego koła jest konieczne, jeśli chce się przerwać podstawowy skutek wygenerowany przez tę samonapędzającą się maszynerię, a mianowicie postępujące faktyczne ograniczenie energii twórczej i życiowej. Warto zauważyć, że „im dalej w las, tym ciemniej”, a więc nawet jeśli w nawykach myślowych jest pewna przewidywalność, choćby katastroficzna, to na którymś etapie tego procesu może być już tak „ciemno”, że nic innego nie pozostanie, tylko rzeczywista katastrofa - jeśli nie przejawiająca się bezpośrednio wypaleniem twórczym, to rozwijającymi się w ciele chorobami ${ }^{14}$, które napędzane różnymi życiowymi decyzjami zyskują tylko na sile, gdy dodatkowo wspomagają je negatywistyczne wizje i myśli (Hammen, 2006; Kabat-Zinn, 2018). Idealnie napędzają tę destrukcję na przykład używki takie jak alkohol, który w układzie nerwowym silnie hamuje produkcję serotoniny i dopaminy, co z biegiem czasu tylko nasila i utrwala ogólny stan rozdrażnienia i braku bezpieczeństwa aż do trwałego poczucia zagrożenia (Brower, 2001; Rachdaoui, Dipak, 2017). Nie wspominając o tym, że słabnie, a nawet zanika spontaniczna skłonność do reagowania przyjemnością w sytuacjach faktycznie

12 Przykładowo: kortyzol, adrenalina, noradrenalina (Stahl, 2008).

13 Właściwie neuroprzekaźników mogących również pełnić funkcje hormonów i odwrotnie - substancji chemicznych produkowanych w układzie nerwowym (całym, a nie tylko w mózgu) przez komórki nerwowe i wykorzystywanych jako molekularna forma komunikacji międzykomórkowej (Stahl, 2008; Longstaff, 2009).

14 Nieunikniony skutek utrwalonego wysokiego poziomu napięcia psychofizjologicznego vide stresu na przykład w obrębie układu hormonalnego, krwionośnego i odpornościowego (Martin, 2011; Schwartz, 2018). 
przyjemnych (Hammen, 2006). Można pokusić się o wniosek, że im więcej negatywistycznej przewidywalności, tym mniej rzeczywistych możliwości - co potwierdzają również obserwacje z praktyki psychologicznej.

\section{Bezrozumna narracja spontaniczna a teraźniejszość i reakcje cielesne}

Osoba twórcza na polu sztuki tym bardziej więc powinna rozważyć wyjście z błędnego koła negatywistycznej, bezrozumnej narracji spontanicznej i czym prędzej oddzielić swoje Ja od treści tej narracji. Kartezjańskie cogito ergo sum jest zwodnicze i w świetle wniosków z badań empirycznych na gruncie nauk o mózgu wyraźnie nieprawdziwe. Można bez wątpienia spojrzeć z perspektywy empirycznej na człowieka jak na istotę, która myśli dlatego, że jest, ale z pewnością nie musi to oznaczać, że jest tym, czym są jego myśli. Myślenie bowiem to proces zarówno celowy, jak i bezcelowy, a same myśli są produktem mózgu z powodu jego aktywności fizykalnej i chemicznej. Nie ma więc powodu, by traktować je inaczej niż każdy inny produkt tej aktywności, na przykład wyobraźnię lub pamięć (Nęcka, Orzechowski, Szymura, 2008; Jaśkowski, 2009; Kahneman, 2011; LeDoux, 2017).

W ujęciu Mindfulness praktykuje się więc traktowanie myśli jak każdego innego wydarzenia mentalnego, które ma swój początek i koniec. Myśli poruszają się płynnie lub skokowo, mają znaczenie, ale również nie mają żadnego znaczenia i można traktować je jako zjawisko samo w sobie, w które za pomocą uwagi można wejść, ale można też z niego wyjść, używając uwagi (Teasdale, Williams, Segal, 2014; Williams, Penman, 2014; Kabat-Zinn, 2018). Jest to możliwe właśnie dzięki odrębności funkcji uwagi od innych funkcji mózgowych (Nęcka, Orzechowski, Szymura, 2008; Jaśkowski, 2009). Choć uwaga w pewnych podstawowych automatycznych (wrodzonych) mechanizmach ściśle współpracuje z innymi funkcjami umysłowymi, na przykład ze zmysłami, to wyraźnie ma również potencjał związany z inną funkcją umysłową, którą jest wola (Nęcka, Orzechowski, Szymura, 2008; Jaśkowski, 2009). Uwaga podąża za wzrokiem zupełnie automatycznie i wzmacnia bodźce przyjmowane wzrokowo, powodując, że ich siła jest w danym momencie (tj. percepcyjnym) większa niż innych bodźców, na przykład słuchowych, czuciowych. Dopiero siła innych niż wzrokowe bodźce musi być w danym momencie znacząco większa, by uwaga podążyła automatycznie za nimi, a ściśle za siłą danego bodźca (Nęcka, Orzechowski, Szymura, 2008; Jaśkowski, 2009). Gdy natomiast zamknie się oczy, od razu można poczuć, że uwaga „rozchodzi się” na inne zmysły, zmieniając proporcje rozłożonego ciężaru - dzięki temu można uświadomić sobie, że wyostrza się to, co stychać lub to, co czuć. To trening uwagi jest właśnie jed- 
ną z fundamentalnych strategii oddziaływania w ujęciu Mindfulness (Kabat-Zinn, 2018). Do takiego treningu niezbędna jest wola i świadomość tego, czym jest teraźniejszość, gdy spojrzy się na nią w świetle wiedzy z psychofizjologii.

Otóż teraźniejszość dzieje się w ciele i we wszystkich procesach, które mają miejsce w określonej chwili percepcyjnej i w związku z tymi myślami, w których w danym momencie zanurzona jest uwaga (Kabat-Zinn, 2018). Jeśli negatywistyczna, bezrozumna narracja spontaniczna absorbuje uwagę, trzymając ją w przeszłości lub w przyszłości, to nie znaczy, że teraźniejszość przestała istnieć. Wręcz przeciwnie, istnieje ona nadal, ale doświadcza jej ciało tego, kto myśli. Jak wspomniałem wyżej, za myślami podążają reakcje fizjologiczne. Myśleniu negatywistycznemu towarzyszy obniżenie nastroju, a to oznacza zupełnie inną konfigurację neurochemiczną niż w sytuacji dobrego nastroju. W sprzężonej z negatywistyczną narracją konfiguracji neurochemicznej ciało doświadcza napięcia ściśle związanego z tą konfiguracją. Myśląc o tym, że coś jest złe, będzie złe, było złe, produkcja hormonów stresu (poczucia zagrożenia) wzrasta, a produkcja hormonów szczęścia (poczucia bezpieczeństwa) maleje (Stahl, 2008; Seligman, 2011). Generuje to mnóstwo zmian w różnych układach organizmu. W układzie oddechowym następuje przyspieszenie oddechu i zmniejszenie pojemności pobieranego powietrza. W układzie krwionośnym dochodzi do przyspieszenia krążenia (wzrostu ciśnienia) i zwiększenia częstotliwości uderzeń serca (pulsu). W układzie trawiennym następuje chwilowe przyspieszenie procesów trawiennych, po czym silne spowolnienie. Kurczliwość mięśni przybiera na sile i częstotliwości, a rozkurczliwość spowalnia (Stahl, 2008; Seligman, 2011). Pod wpływem negatywistycznej narracji w ciele obserwuje się również wiele innych skutków ${ }^{15}$. Procesy zachodzące w ciele w czasie, w którym uwaga podąża za treścią wewnętrznej, negatywistycznej, bezrozumnej narracji spontanicznej, są realne i dzieją się tu i teraz, a zatem są teraźniejszością! Jeśli nie skupi się uwagi na teraźniejszości, to nie wyjdzie się z błędnego koła tej narracji. Tak więc trening intencjonalnego kierowania uwagą po to, by za każdym razem, gdy podąży za negatywistyczną narracją, wróciła do teraźniejszości, prowadzi w istocie do wytworzenia wewnętrznej przestrzeni umysłowego kontaktu z teraźniejszością (Kabat-Zinn, 2018). W tym treningu spontaniczne myśli tworzące negatywistyczną narrację nie mogą być traktowane inaczej niż wydarzenia mentalne, a ciało musi być przestrzenią świadomego kontaktu z teraźniejszością poprzez jego doznania. Dlatego podstawową techniką tego treningu jest tak zwana medytacja kierowana, w której kluczową rolę odgrywa intencja uważnej czynności (Kabat-Zinn, 2018).

15 Związek konkretnych reakcji zachodzących w organizmie pod wpływem myśli jest bardzo dobrze udokumentowany w badaniach empirycznych na gruncie zarówno psychologii i wielu jej dziedzin, jak i neurobiologii, neuronauki i medycyny. 


\section{Medytacja kierowana, mózg i samopoczucie}

Jedną z najbardziej podstawowych medytacji kierowanych jest medytacja oddechem, w której chodzi wyłącznie o intencjonalnie uważne oddychanie, z założeniem, że przebiega ono w naturalnym dla danego człowieka rytmie (Teasdale, Williams, Segal, 2014; Williams, Penman, 2014; Kabat-Zinn, 2018). Jak wynika z wielu badań nad wpływem kilkuminutowej medytacji oddechem, tylko przekierowanie uwagi na sam proces oddychania i uważne, wewnętrzne, pozbawione werbalizacji obserwowanie tego procesu i odczuwanie go w ciele natychmiastowo wpływają na mózg, zmieniając jego elektromagnetyczność korową (van Lutterveld i wsp., 2017). W trakcie tej czynności następuje automatyczna zmiana w konfiguracji podstawowych częstotliwości fal elektromagnetycznych, co de facto oznacza, że sprzężone z dużym pobudzeniem organizmu fale beta ustępują zyskującym przewagę falom alfa, które sprzęgają się ze stanem odpoczynku, ukojenia, uspokojenia, poczucia bezpieczeństwa (van Lutterveld i wsp., 2017).

Badania długoterminowe wykazały, że po roku regularnej medytacji oddechem, trwającej dziesięć minut i praktykowanej tylko raz w tygodniu przez osoby z utrwaloną konfiguracją korowego pobudzenia elektromagnetycznego zdominowanego przez fale beta (doświadczające różnych skutków tego stanu, np. wzmożonej nerwowości, różnych form bezsenności, częstej gonitwy negatywnych myśli), zaobserwowano u tych osób trwałą zmianę nie tylko w zakresie symptomów psychicznych i behawioralnych, ale również w zakresie konfiguracji korowej aktywności elektromagnetycznej, w której obecność fal beta była istotnie różna niż fal alfa. Nie dziwi więc fakt, że to właśnie osoby regularnie medytujące, jak wynika z badań empirycznych, przejawiają najniższe parametry lęku wyjściowego w efekcie takiego treningu (van Lutterveld i wsp., 2017).

Medytacja kierowana to technika pozwalająca trenować kierowanie uwagą zgodnie z własną intencją, nie pozwalając jej w istocie podążać spontanicznie za toksyczną narracją (Kabat-Zin, 2018). Dzięki medytacji kierowanej nie trzeba prowadzić częstokroć frustrującej walki z trudnymi myślami, wystarczy ćwiczyć świadome wyjmowanie z nich swojej uwagi, traktując je jak wydarzenia mentalne, które pojawiają się i znikają - tylko uwagą można je zatrzymywać, a więc również porzucać (Teasdale, Williams, Segal, 2014; Kabat-Zin, 2018). Konieczne jest zatem trenowanie uwagi, żeby nie zatrzymywać w polu percepcyjnym myśli negatywistycznych. To dlatego między innymi w medytacji kierowanej ważne jest nie tylko świadome obserwowanie swojego oddechu, ale i całego ciała w tym, czego doświadcza ono w danym momencie, a zwłaszcza w momencie nasilonego napięcia pod wpływem negatywistycznej narracji (Teasdale, Williams, Segal, 2014; 
Kabat-Zin, 2018). W ten sposób same myśli nie tylko mogą zostać porzucone za pomocą uwagi na rzecz doznań w ciele, ale również mogą zostać skutecznie potraktowane (np. podważone za pomocą technik poznawczo-behawioralnych) z perspektywy obserwatora, a nie wchłoniętego przez nie uczestnika.

Obserwowanie siebie w swojej cielesności pozwala na większy kontakt z teraźniejszością i jednocześnie wyznacza granicę między Ja cielesnym obecnym tu i teraz, prawdziwym a Ja interpretacyjnym, wynikającym z nacechowanej oceną i wartościowaniem narracji zdominowanej przez werbalizację). Bycie obserwatorem własnych doznań fizycznych i psychicznych, w tym rozmaitych wydarzeń mentalnych, ułatwia utrzymywanie dystansu wobec rzeczywistości interpretacyjnej, pełnej subiektywizmu i zniekształceń poznawczych (Teasdale, Williams, Segal, 2014; Kabat-Zin, 2018).

Podobny rezultat można osiągnąć, praktykując za pomocą sterowania uwagą wykonywanie rozmaitych rutynowych czynności, takich jak sprzątanie, mycie się, jedzenie itp. Trenując uważność w czynności wykonywanej w danym momencie, zyskuje się pełniejszy jej wymiar. Uważnie obserwując choćby własną czynność jedzenia i płynące z niej doznania, wzbogaca się paletę tych doznań i jednocześnie utrudnia oddalanie się od tej czynności w czas i przestrzeń wynikające ze spontanicznej narracji (Teasdale, Williams, Segal, 2014; Kabat-Zin, 2018). To dlatego ogromnie ważne jest, by trenując postawę nieoceniającego obserwatora, intencjonalnie redukować jednocześnie ocenianie tego, co się obserwuje (Teasdale, Williams, Segal, 2014; Stark, 2017; Kabat-Zin, 2018). Techniką medytacyjną może więc być wszystko, jeśli spełnia podstawowe kryteria uważnego uczestnictwa w teraźniejszości.

\section{Dziennik malarski jako narzędzie samoobrony}

Dziennik malarski może być przejawem spontanicznej aktywności poznawczej, a także artystycznej aktywności, ale nie oznacza to, że musi mieć artystyczny cel. Podobnie jak dziennik literacki malarska forma wypowiedzi jest przykładem wyrażonej przez autora potrzeby wypowiedzenia się. Jeśli tej formie aktywności towarzyszy intencja wytworzenia dzieła sztuki (literackiego, malarskiego, muzycznego), to z pewnością realizacja tego celu będzie przynajmniej częściowo podporządkowana pojęciom związanym z artystyczną wartością, na przykład w zakresie samej formy wyrazu. Jeśli jednak cel dziennika nie jest związany z potrzebą wytworzenia dzieła sztuki, ale ma całkowicie osobiste motywacje, na przykład danie upustu własnym emocjom, to przestaje być dziełem per se, a zaczyna być czynnością 
pomocną w radzeniu sobie z wewnętrzną frustracją. Oczywiście jedno nie wyklucza drugiego, ale cel artystyczny nie musi być zbieżny z celem osobistym i odwrotnie.

Dziennik malarski Weroniki Naszarkowskiej-Multanowskiej jest przykładem dzieła artystycznego, ale wynikłego z osobistych, a nie artystycznych celów. Można powiedzieć, że początkowo było to niejako przypadkowe dzieło artystyczne czy też walor artystyczny dziennika był jego drugoplanowym aspektem w porównaniu do pierwszoplanowej emocjonalnej potrzeby poprawienia sobie nastroju. $Z$ założenia nie realizuje on więc dążeń artystycznych malarki, ale potrzebę uporania się z wewnętrzną frustracją dnia codziennego, a przede wszystkim z silnym napięciem psychofizycznym, którego artystka doświadcza w okresach niemocy twórczej. Jak wynika z wypowiedzi malarki, potrzeba malowania jest u niej sama w sobie na tyle ważna i silna, że manifestuje się niezależnie od tego, czy doświadcza ona w danym momencie poczucia wzrostu, czy też spadku energii twórczej.

W okresach wzrostu energii twórczej malarka tworzy obrazy o tematyce ściśle związanej z jej aspiracjami artystycznymi, które wymagają umiejętności i czynności malowania traktowanej jako środek do celu, a nie cel sam w sobie. Wśród tych dążeń artystycznych jest więc napięcie między kolorami, zamierzona rezygnacja z perspektywy klasycznej na rzecz dążenia do wydobycia głębi jedynie za pomocą koloru, czasami też zaskakująco silne zderzenie płaszczyzn koloru. Te formalne aspekty swoich zawodowych dążeń Naszarkowska-Multanowska realizuje w tematyce zdominowanej przez wnętrza o wyraźnie scenograficznym charakterze, co w sposób nieunikniony wynika również z jej bogatego doświadczenia zawodowego jako scenografki telewizyjnej i teatralnej. W jej obrazach widać więc grę kolorów ścierającą się z niemal rozsypującymi się płaszczyznami wzorzystych tkanin. Obrazy malarki pozbawione są figuratywnej narracji, a nie będąc w ścisłym tego słowa znaczeniu obrazami abstrakcyjnymi, zdają się graniczne zarówno w formie, jak i w treści. Pozorna nieudolność w formalnej warstwie elementów figuratywnych jest celowym zabiegiem na rzecz dążenia do zmaksymalizowania wpływu płaszczyzn koloru na treść obrazu i na odbiorcę. Podobnie sam temat elementów figuratywnych jest celowo strywializowany, bo nie chodzi w nim o martwą naturę jako dążenie artystyczne, ale o melancholię dnia codziennego, wyrażoną w zniekształceniach formy. Tę aurę melancholii Naszarkowska-Multanowska wydobywa w swoich obrazach właśnie ze swoistego lekceważącego potraktowania zarówno elementów figuratywnych, jak i samej perspektywy. Ujmując rzecz z punktu widzenia psychologii, w melancholii nie postrzega się świata o ostrych, zwartych i proporcjonalnie skonfigurowanych krawędziach tworzących ład i porządek (Hammen, 2006; Seligman, 2011). W melancholii nie tylko zacierają się granice czasoprzestrzenne, ale wiele elementów nawet bardzo proporcjonalnych 
może wydawać się mocno zniekształconymi - analogicznie do zniekształceń poznawczych w schematach myślenia zwerbalizowanego (Hammen, 2006; Beck, 2011; Seligman, 2011). Wrażenie rozsypywania się przestrzeni w obrazach artystki koresponduje zatem ze stojącym w miejscu czasem, a figury pozostawione w nieładzie są nie tylko nasycone zniekształceniem percepcyjnym, ale również melancholijnym zaniedbaniem - jakby były tylko z konieczności, a nie dla użyteczności. To dlatego w obrazach Naszarkowskiej-Multanowskiej symboliczna melancholijna pustka wzmocniona jest przez równie melancholijną ulotność przestrzenną. Można mieć wrażenie, że wnętrza obrazów malarki powstały nie tylko w nerwowym pośpiechu, ale również w nerwowej obawie, że za chwilę znikną i nie pozostanie po nich ślad. Obrazy te są więc swoistym zapisem melancholii, uwidaczniającej się w napięciu kolorystycznym wzorzystych płaszczyzn i będącej jednocześnie dążeniem artystycznym równoprawnym z napięciem kolorystyczno-przestrzennym.

Natomiast dziennik malarski jest zapisem codzienności, ale nie dla niej samej, tylko dla autorki, która jest w tym zamierzeniu nie tylko narratorką, ale również centralną postacią - bohaterką, wokół której kręci się cały świat. Nie można więc powiedzieć, że dziennik malarski Weroniki Naszarkowskiej-Multanowskiej jest zapisem rzeczywistości czy też refleksji na temat rzeczywistości, czego można by się spodziewać po samej idei dziennika. Wyraźnie jednak wynika z treści omawianego dziennika, że jest on zapisem Ja subiektywnego autorki, wytwarzanego w zderzeniu ze zróżnicowaną rzeczywistością. Autorka nie przedstawia w nim świata i ludzi, tylko siebie i fragment świata, który jej dotyczy w danym momencie. Wygląda to tak, jakby subiektywna narracja wewnętrzna artystki znalazła się wprost na kartach tego dziennika. Wyraźna emocjonalność artystki jest tak silnie scentralizowana, że nawet wtedy, gdy pojawiają się inni ludzie, można odnieść wrażenie, że są oni nieemocjonalni, choć zdecydowanie zachowują status bodźca wyzwalającego emocje.

\section{Dziennik malarski jako medytacja kierowana}

Malarka poczuła potrzebę malowania dziennika w związku z coraz dłuższymi i coraz bardziej dojmującymi okresami niemocy twórczej, przy jednoczesnym poczuciu, że życie sprowadza na nią coraz trudniejsze doświadczenia, na przykład choroby, problemy bytowe czy inne nagłe i trudne wyzwania życiowe - osobiste, społeczne, rodzinne. Początkowo dziennik był malowany tylko dla siebie i nikomu nie był pokazywany. Malarka podkreśla, że dotyczy on tylko potrzeby malowania, która jest równie silna wtedy, gdy nie może ona malować obrazów realizujących jej dążenia artystyczne i cele zawodowe. Już sama czynność malowania jest dla 
Naszarkowskiej-Multanowskiej tak dużą przyjemnością, że wystarczy jako motywacja, dając wyraźną poprawę nastroju. Co więcej, ta przyjemność nie wiąże się z tym, co zostanie namalowane, ale z samym faktem malowania. Stąd tematy dziennika malarskiego są zupełnie prozaiczne. To analogiczny do dziennika literackiego zapis spostrzeżeń, odczuć i wrażeń artystki, która broni się przed rosnącą frustracją twórczą i życiową. Jest to jednak zapis malarski, a więc odzwierciedla myślenie obrazem, tudzież wzrokowe.

Bez wątpienia ten intuicyjny, samoobronny gest malarki wpisuje się w ideę medytacji kierowanej, realizując podstawowy cel tej techniki, a więc poprawę nastroju. Autorka często podkreśla, że sama czynność malowania daje jej tak wiele przyjemności, że w trakcie jej wykonywania nic innego nie ma znaczenia. O to właśnie chodzi w czynności, którą traktuje się intencjonalnie i z całkowitą uważnością - jako cel sam w sobie! Nabiera to jeszcze większej wartości psychologicznej, gdy uświadomimy sobie, że autorka nie dokonuje oceny tego, jak maluje, gdy maluje dziennik, bo nie ma to dla niej większego znaczenia. Wielokrotnie podkreśla, że w dzienniku wszystko „przejdzie”, każda nieudolność i poślizgnięcie pędzla - w przeciwieństwie do sytuacji malowania obrazu realizującego cele artystyczne. Wtedy samo malowanie już nie wystarcza, a towarzyszy mu nieustające wewnętrzne ocenianie tego, co malarka chce osiągnąć w obrazie. Dlatego między stanem emocjonalnym towarzyszącym malowaniu dziennika a emocjami pojawiającymi się podczas malowania obrazu jest istotna różnica, jak wynika z rozmów z malarką. Malowanie obrazów to ciągłe mocowanie się z frustracją, podczas gdy malowanie dziennika zapewnia czystą przyjemność - nawet jeśli treścią są kwestie niezbyt przyjemne.

Z perspektywy psychologicznej rola dziennika malarskiego w życiu Naszarkowskiej-Multanowskiej jest fundamentalna, bo wywołuje przeciwważne do frustracji stany psychiczne i chroni artystkę przed utonięciem w sile samonapędzającego się negatywizmu. Z perspektywy kilku lat, w ciągu których powstaje dziennik (od roku 2009), artystka zauważyła, że okresy niemocy twórczej stały się krótsze i mniej dojmujące, a zdarza się, że okresy przypływu siły twórczej są znacznie dłuższe i bardziej owocne niż w latach, kiedy nie prowadziła dziennika. Taki rezultat nie dziwi w świetle przytoczonych wyżej informacji o podstawowych mechanizmach psychofizjologicznego podłoża stresu. Skoro artystka doświadcza przyjemności, uspokojenia i ukojenia, malując dziennik, to znaczy, że czynność ta wyraźnie stymuluje w niej wydzielanie serotoniny, dopaminy, endorfin, oksytocyny i hamuje jednocześnie wydzielanie glikokortykosteroidów, czyli hormonów stresu.

Warto zauważyć, że intuicyjne poszukiwania ratunku dla siebie samego w chwilach silnie spadającego nastroju pod wpływem często „znoszących” człowieka fal negatywizmu mogą nie tylko okazać się pomocne, ale również przypadkowo spełniać 
kryteria podstawowych, zweryfikowanych empirycznie technik psychologii stosowanej. Weronika Naszarkowska-Multanowska postanowita naturalną koleją rzeczy sięgnąć po to, co jest dla niej najważniejsze w jej codziennej aktywności i jednocześnie jest jej naturalnym sposobem komunikowania się ze sobą i otoczeniem. Myślenie nie sprowadza się bowiem tylko do werbalizacji, ale ma prostsze formy, takie jak choćby obraz czy dźwięk i już one mogą wystarczyć, by nie tylko wyrazić określoną treść, ale również posłużyć do przeformułowań negatywistycznej, subiektywnej narracji wewnętrznej. W dzienniku artystki jest wiele sytuacji z codzienności, które są wyraźnie nasycone silnymi przeżyciami wewnętrznymi, na przykład lękiem. Dziennik pozwala jednak nie tylko zdystansować się od nich poprzez zmianę nastroju samą czynnością malowania, ale również nadać wcześniejszym przeżyciom i zdarzeniom inny walor - humorystyczny, kontemplacyjny itp. W ten sposób dziennik staje się intuicyjnie trafnym, osobistym, autoterapeutycznym narzędziem zmiany nastroju i jednocześnie przestrzenią dialogu z własnym Ja. To właśnie ten swoisty dialog pozwala autorce spowolnić szybkie myślenie i nazwać własne odczucia oraz nastawienie do codzienności, a zarazem kontrolować formę ich wyrazu.

\section{Dziennik malarski, komunikacja i przeformułowania zwerbalizowane}

Dodatkowy pozytywny skutek prowadzenia dziennika malarskiego wyniknąt z przestrzeni kontaktów społecznych autorki. To naturalne, że w okresach spadku nastroju człowiek wycofuje się z kontaktów społecznych, przyjmując kierunek wewnętrzny we własnym przeżywaniu. Naszarkowska-Multanowska nie jest pod tym względem wyjątkiem. Nie oznacza to jednak, że nie potrzebuje kontaktu z ludźmi. Jak wiadomo, podtrzymywanie więzi społecznych jest jednym z podstawowych warunków dobrostanu psychicznego (Hammen, 2006). Malując dziennik, autorka ogląda siebie i własne przeżycia, ale również uczy się dostrzegać więcej przyjemnych chwil w codziennym funkcjonowaniu. Sieć kontaktów społecznych, którą tworzy rodzina i przyjaciele malarki, jest dla niej ważną przestrzenią przejawiania się jej emocjonalności. Z tego powodu w którymś z okresów prowadzenia dziennika artystka na pytanie „Co słychać?”, zadane mailem przez kilku przyjaciół, odpowiedziała, wysyłając zdjęcie jednej z kart swojego dziennika. Jak łatwo się domyślić, gest ten spotkał się ze zrozumieniem, współodczuwaniem i entuzjazmem. Okazało się bowiem, że osoby otrzymujące mailem karty dziennika reagują spontanicznie, wyraźnie wskazując, że w tym, co zobaczyły, rozpoznają również swoje własne doświadczenia emocjonalne. Zmotywowana w ten sposób 
autorka zaczęła używać dziennika dodatkowo jako formy komunikowania się z wąską grupą kilku najbliższych osób za pomocą poczty elektronicznej, tym samym również stymulując i wzmacniając wewnętrzny efekt poprawy nastroju. W ten sposób, niejako przypadkowo i z konieczności, wyłonił się istotny element dziennika, a mianowicie tytuły poszczególnych jego kart. Artystka nie zwracała uwagi na ten aspekt (najwcześniejsze karty nie mają tytułów), dopóki nie okazało się, że tytułu potrzebuje nie tyle sama karta, ile mail do przyjaciół zawierający określoną kartę dziennika. Warto mieć świadomość, że dla artysty wizualnego obraz jest twierdzeniem - czego wyraźnie i skutecznie dowodzit już w latach sześćdziesiątych XX wieku Rudolf Arnheim w swoich fundamentalnych pracach o myśleniu wzrokowym (Arnheim, 2004; 2011).

Dziennik zyskat więc praktyczny, ale również istotny z perspektywy psychologicznej i artystycznej dodatkowy element w postaci tytułu. Nadawanie tytułu każdej jego karcie jest od tamtej pory „kropką nad i”, dodawaną po namalowaniu karty. Oczywiście wybór tematu zarówno w początkowych etapach tworzenia dziennika, jak i obecnie jest związany z tym, co danego dnia autorkę najbardziej zaabsorbuje - poza całkowicie bazowo absorbującą potrzebą malowania w czasie niemożności tworzenia obrazu. Tytuły kart dziennika stały się więc nie tylko ich identyfikatorami, ale i współwystępującą z obrazem dodatkową formą wyrazu siebie, choć tylko częściowo, bo tytuł dotyczy karty dziennika, a nie samej bohaterki dziennika, choć jest ona centralną postacią jej treści.

Warto zauważyć, że tytuły są możliwie najprostsze i najczęściej oznajmujące. Jeśli przywołać tak zwane techniki poznawczo-behawioralne, najskuteczniejsze wraz z Mindfulness na gruncie psychologii stosowanej formy oddziaływania w zaburzeniach lękowych i depresyjnych, to warto zauważyć, że wśród nich jedną z fundamentalnych jest modyfikowanie zniekształceń poznawczych (Beck, 2011). Do tego celu konieczne jest posługiwanie się językiem, a jego struktura jest intensywnie wykorzystywana do przeformułowań tego, co myślane w języku, skrajnie subiektywne i negatywistyczne, na to, co realistyczne, faktograficzne i hamujące spadek nastroju lub nawet poprawiające go (Beck, 2011). Przykładem może być różnica między stwierdzeniami: „Głupia czapla wyskoczyła mi na drogę i przez nią mało serce mi nie pękło” a "Nagle na łąkach pojawiła się biała czapla" (jak proponuje Naszarkowska-Multanowska w jednej z kart swojego dziennika). W pierwszym stwierdzeniu jest wyraźne wartościowanie ujemne, a w drugim zwykłe stwierdzenie faktu. Pierwsze stwierdzenie jest przykładem schematu wartościowania ujemnego, który regularnie stosowany obniża nastrój 
i utrzymuje go na niskim poziomie ${ }^{16}$. Drugie stwierdzenie nie jest nacechowane ujemną oceną, a więc bliższe jest nie tylko obiektywnej rzeczywistości, ale również wyraża postawę uczestniczącego obserwatora, ale nie oceniającego. Nawet w tytułach, w których zostają użyte przymiotniki lub inne części mowy wyraźnie oceniające, takie jak określenie „cudownie” w tytule Jak cudownie nawet gdy spłonie konfitura brzoskwiniowa [...], nie wydaje się to mieć charakteru wymuszonego optymizmu w obliczu kłopotu, którym jest choćby przypalenie konfitury. W takiej sytuacji przymiotnik raczej wskazuje na akceptację zaistniałej sytuacji i towarzyszącą tej akceptacji świadomość, że sytuacja już się dokonała i nie da się jej cofnąć. Nawet tytuł fundamentalnej dla ujęcia Mindfulness książki Jona Kabata-Zina Życie, piękna katastrofa wskazuje na taki, a nie inny wydźwięk przymiotnika użytego w odniesieniu do życia. Tytuły kart pamiętnika malarskiego Weroniki Naszarkowskiej-Multanowskiej tworzą więc również przestrzeń przeformułowań doświadczonej frustracji i niejako uzupełniają treść malarską.

\section{Ryzyko związane z dziennikiem malarskim}

Po wielu latach od zainicjowania dziennika malarskiego i regularnie doświadczanych przez autorkę pozytywnych reakcji kilkorga osób, którym jego karty były udostępniane w ramach przyjacielskiego dialogu, jego podstawowa rola, to znaczy regulowanie spadków nastroju i okresów niemocy twórczej w życiu autorki, pozostaje niezmienna, ale dziś konfiguruje się już z dodatkowymi funkcjami. Oprócz tego, że dziennik jest narzędziem komunikacji społecznej, to dodatkowo stał się jeszcze przestrzenią kontrolowania tej komunikacji na linii nadawca - odbiorca. Nastrój odbiorcy nie jest tu bez znaczenia. Nie można więc wykluczyć, że sam fakt okresowego udostępniania dziennika już nie tylko drogą poczty elektronicznej i nie tylko garstce osób, z którymi kontakt ma faktyczną dodatnią wartość dla autorki, ale również na profilu społecznościowym przynajmniej kilkudziesięciu znajomym, wśród których są także osoby nienależące do grona bliskich, wpływa na funkcję dziennika, zacierając jego podstawowy cel. Niesie to ryzyko zachwiania równowagi między wpływem dziennika na artystkę a jego oddziaływaniem na inne osoby, które stają się aktywną i życzliwą, jednak - chcąc nie chcąc - publicznością tego dzieła. Jeśli artystka zachowa kontrolę nad tą równowagą i nie ulegnie pochlebstwom oraz własnym wyobrażeniom o oczekiwaniach dalszego odbiorcy, to z dużym prawdopodobieństwem dziennik pozostanie w swej

16 Prowadząc, prędzej czy później, do ogólnego wrażenia, że wszystkie czaple lub wszystkie nagle wyskakujące na drogę zwierzęta, a być może i ludzie są głupi, co w warstwie ukrytej może nieść potwierdzenie przekonania pośredniczącego, że świat jest głupi i niewiele wart. 
podstawowej funkcji istotnie sprawczy. Jeśli jednak autorka ulegnie poklaskowi lub zniekształceniom poznawczym o publiczności, to może wpaść w pułapkę frustracji związanej z potrzebą zyskania aprobaty społecznej i manipulować treścią dziennika, spekulując, co może bardziej spodobać się tym, którzy go oglądają. A to już niesie poważne ryzyko, że dziennik zmieni charakter z narzędzia psychologiczno-artystycznego na projekt artystyczny o psychologicznym, ale jednocześnie komiksowo-satyrycznym wydźwięku. Wyraźnie widać zatem, że nawet skuteczne i świetnie dopasowane indywidualnie narzędzie autoterapeutyczne może stracić swoją moc, jeśli wymknie się z rąk i zmieni się jego kontekst.

Tymczasem dziennik liczy już kilka tysięcy kart, a jego wartości psychologiczna i artystyczna łączą się ze sobą, tworząc przestrzeń niepowtarzalną i wysoce oryginalną na styku nauk humanistycznych, społecznych, przyrodniczych i medycznych. Dziennik malarski Weroniki Naszarkowskiej-Multanowskiej jednoznacznie potwierdza, że sztukę można tworzyć i interpretować dzięki wiedzy o zjawiskach psychicznych, integrując ze sobą przestrzenie dziedzin naukowych.

\section{Bibliografia}

Arnheim R. (2004), Sztuka i percepcja wzrokowa. Psychologia twórczego oka, przeł. J. Mach, Łódź: Wydawnictwo Officyna.

Arnheim R. (2011), Myślenie wzrokowe, przeł. M. Chojnacki, Gdańsk: Wydawnictwo słowo/obraz terytoria.

Beck J.S. (2011), Cognitive Behavior Therapy. Basics and Beyond, New York: Guilford Press.

Brower K.J. (2001), Alcohol Effect's on Sleep in Alcoholics, „Alcohol Research and Health”, vol. 25(2), s. 110-125.

Carlson N.R. (2005), Foundations of Physiological Psychology, Boston: Pearson Allyn \& Bacon.

Cozolino L.J. (2004), Neuronauka w psychoterapii, przeł. J. Gilewicz, Poznań: Wydawnictwo Zysk i S-ka.

Damasio A. (2018), Dziwny porządek rzeczy. Życie, uczucia i tworzenie kultury, przeł. A. Jankowski, Poznań: Dom Wydawniczy Rebis.

Goleman D., Lama D. (2004), Destructive Emotions and How We Can Overcome Them. A dialogue with The Dalai Lama narrated by Daniel Goleman, London: Bloomsbury.

Hammen C. (2006), Depresja. Modele kliniczne itechniki terapeutyczne dla praktyków i pacjentów, przeł. M. Trzebiatowska, Gdańsk: Gdańskie Wydawnictwo Psychologiczne.

Jaśkowski P. (2009), Neuronauka poznawcza. Jak mózg tworzy umysł, Warszawa: Wydawnictwo Vizja Press.

Kabat-Zinn J. (2018), Życie, piękna katastrofa, przeł. R. Skrzypczak, Warszawa: Wydawnictwo Czarna Owca.

Kahneman D. (2011), Thinking Fast and Slow, London: Penguin Books.

Kalat J.W. (2006), Biologiczne podstawy psychologii, Warszawa: Wydawnictwo Naukowe PWN.

LeDoux J. (2017), Lęk. Neuronauka na tropie źródeł lęku i strachu, przeł. M. Hołot, K. Wołoszyn-Hołot, Kraków: Copernicus Center Press.

Longstaff A. (2009), Neurobiologia, przekł. zbiorowy pod red. A. Wróbla, Warszawa: Wydawnictwo Naukowe PWN.

Lutterveld R. van, Dellen E. van, Pal P., Yang H., Stam C.J., Brewer J. (2017), Meditation is associated with increased brain network integration, ,Neuroimage”, vol. 158, s. 18-25, https://doi.org/10.1016/j.neuroimage.2017.06.071

Martin P. (2011), Umyst, który szkodzi. Mózg, zachowanie, odporność i choroba, przeł. P. Turski, Warszawa: Wydawnictwo Muza.

Nęcka E., Orzechowski J., Szymura B. (2008), Psychologia poznawcza, Warszawa: Academica Wydawnictwo SWPS, Wydawnictwo Naukowe PWN.

Padesky Ch.A., Greenberger D. (2004), Umysł ponad nastrojem. Podręcznik terapeuty, przeł. M. Sota, Kraków: Wydawnictwo Uniwersytetu Jagiellońskiego. 
Rachdaoui N., Dipak K.S. (2017), Pathophysiology of the Effects of Alcohol Abuse on the Endocrine System „AAlcohol Research: Current Reviews", vol. 38(2), s. 255-276.

Reber A.S., Reber E.S. (2008), Słownik psychologii, red. I. Kurcz, K. Skarżyńska, przeł. J. Kowalewska, G. Mizera, Warszawa: Wydawnictwo Naukowe Scholar.

Schwartz M. (2018), Strażnicy mózgu. Neuroimmunologia. Nowa nauka, dzięki której nasze mózgi będq zdrowsze i sprawniejsze, przeł. M. Chojnacki, Kielce: Wydawnictwo Charaktery.

Seligman M. (2011), Flourish: A Visionary New Understanding of Happiness and Well-Being, New York: Free Press.

Stahl S.M. (2008), Stahl's Essential Psychopharmacology. Neuroscientific Basis and Practical Applications, Cambridge: Cambridge University Press.

Stark E. (2017), Is Slowness the Essence of Knowledge?, "Ihe Psychologist", vol. 30(7), s. 38-41.

Teasdale J., Williams M., Segal Z. (2014), The Mindful Way Workbook. An 8-week Program to Free Yourself from Depression and emotional Distress, New York: The Guilford Press.

Williams M., Penman D. (2014), Mindfulness a Practical Guide to Finding Peace in a Frantic World, London: Piatkus.

\section{Ilustracje}

Weronika Naszarkowska-Multanowska, Dziennik malarski (czasami zwany też pamiętnikiem), technika gwaszu na papierze. Wszystkie prezentowane poniżej karty mają rozmiar $33 \times 40 \mathrm{~cm}$, fot. D.J.Ż. i Klara Naszkowska

Źródło: archiwum autora, reprodukowane za zgodą Weroniki Naszarkowskiej-Multanowskiej

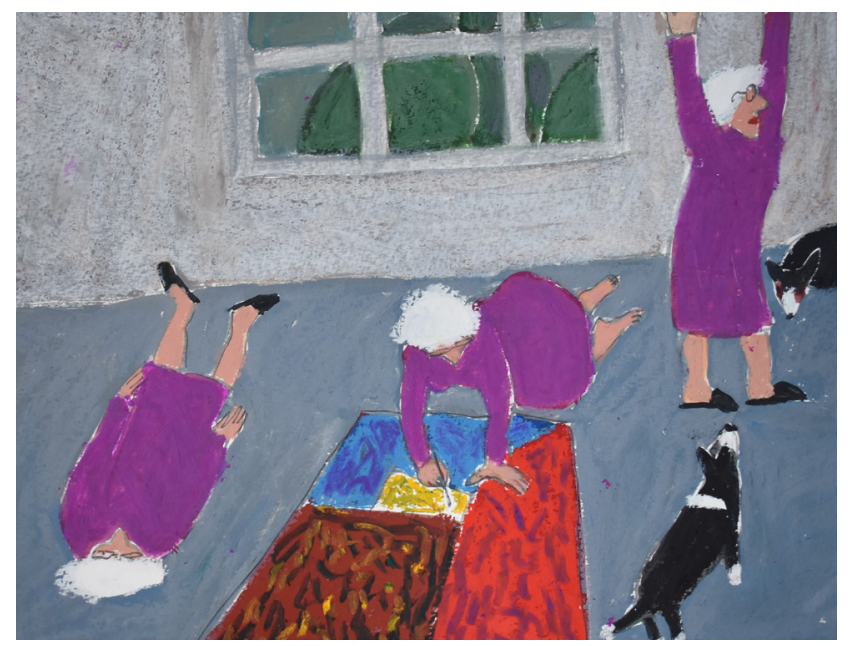

Ilustracja 1

Dziennik malarski, 2017:

Kręgostup boli, mrokzapada, a obraz

nie chce staną́ 


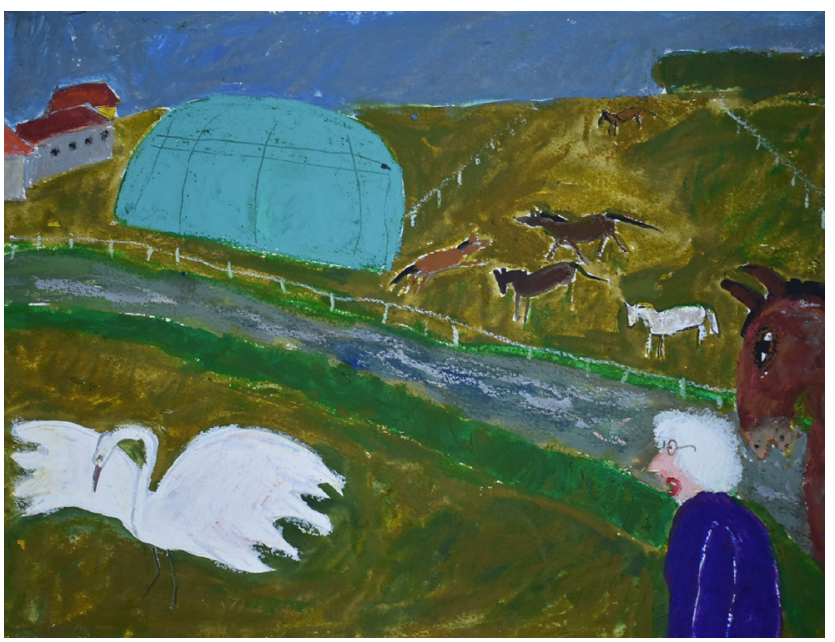

Ilustracja 2

Dziennik malarski, 2017:

Nagle na łąkach pojawiła się biała czapla

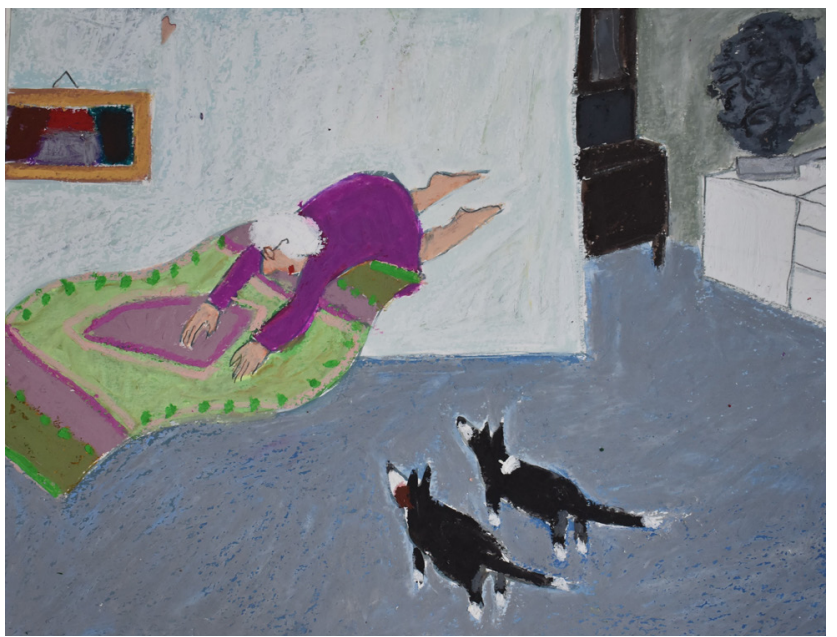

Ilustracja 3

Dziennik malarski, 2017: Jak cudownie nawet gdy spłonie konfitura brzoskwiniowa i gdy przyjaciele przyślą dywanik ratunkowy

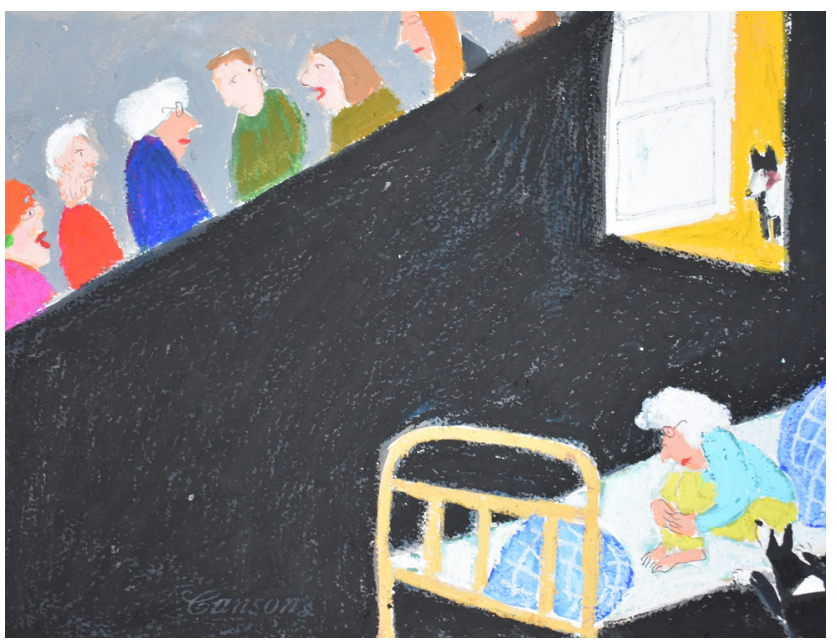

Ilustracja 4

Dziennik malarski, 2017:

Pierwszy dzień na uniwersytecie. Dużo obcej energii 


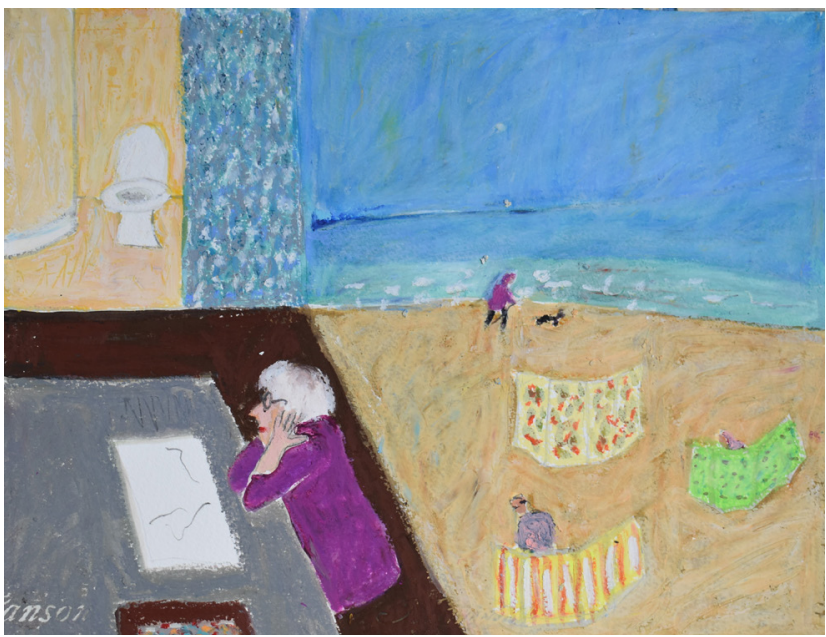

Ilustracja 5

Dziennik malarski, 2017:

Dylemat: iść nad morze czy malować?

Ilustracja 6

Dziennik malarski, 2017:

Sq dni, w których tylko kolor daje

satysfakcje

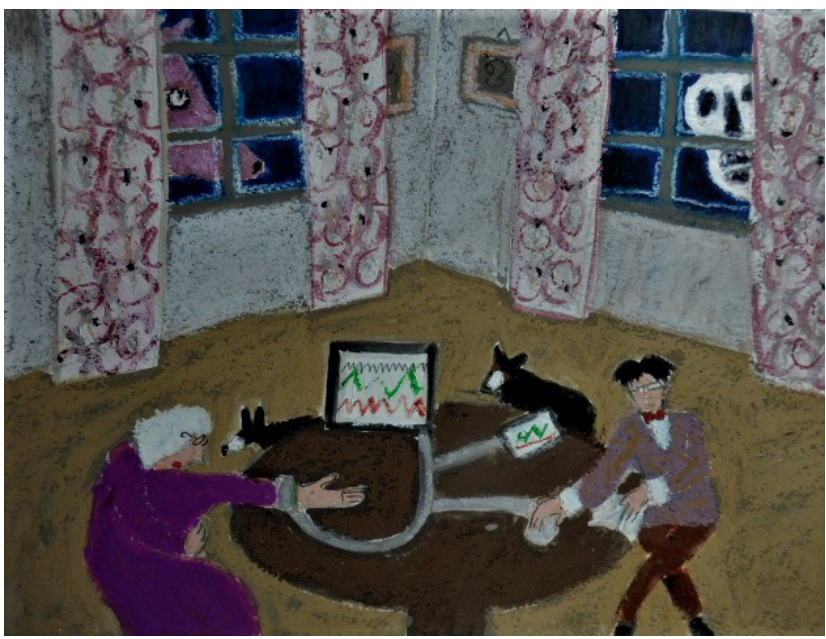

Ilustracja 7

Dziennik malarski, 2018:

Przy następnej wizycie Pan Daniel ma mierzyć poziom lęku. Już strach 




Ilustracja 8

Dziennik malarski, 2017:

Przyczyna głębokiej dezorientacji

może być halny, albo i nie

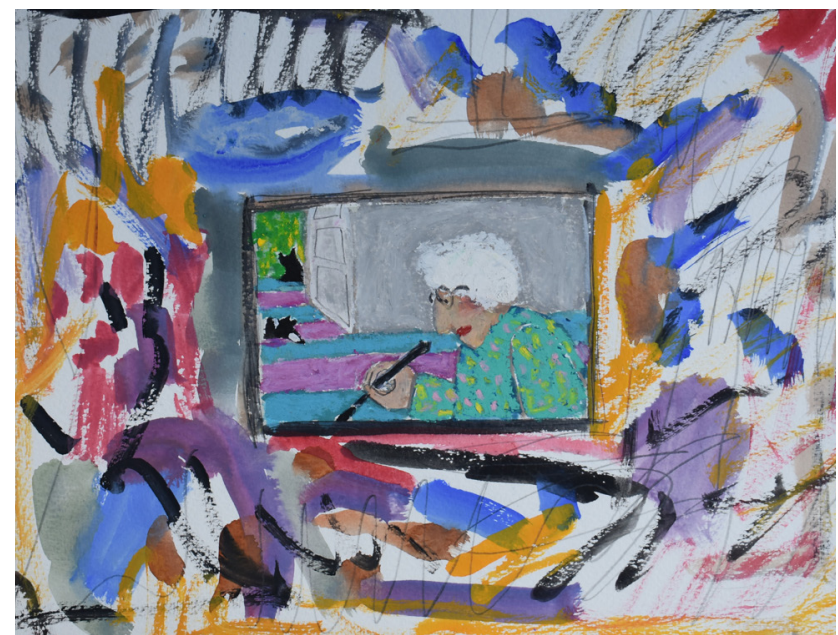

Ilustracja 9

Dziennik malarski, 2016:

Czasami MALOWANIE zabiera tyle energii, że starczy tylko na bardzo mały obrazek

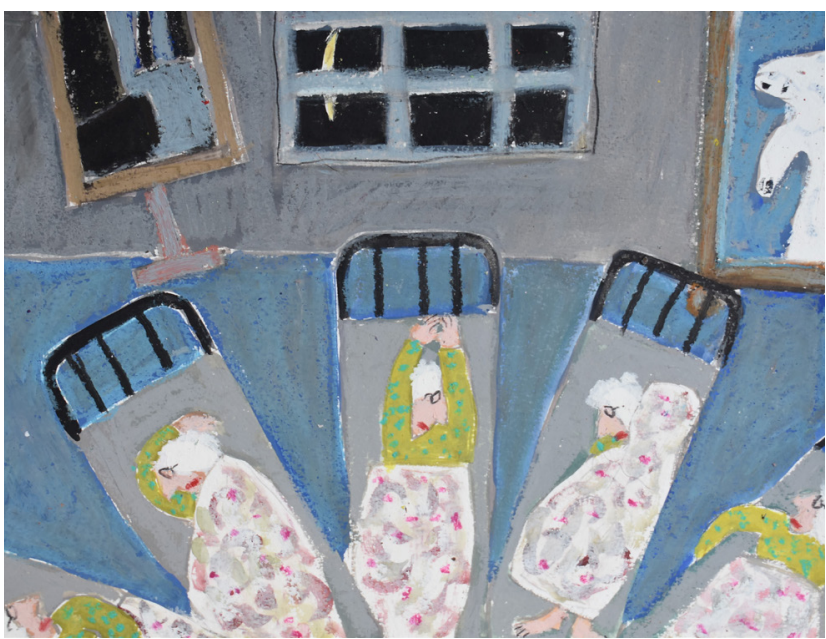

Ilustracja 10

Dziennik malarski, 2016:

Czasem w bezsenną noc pojawi się duch 


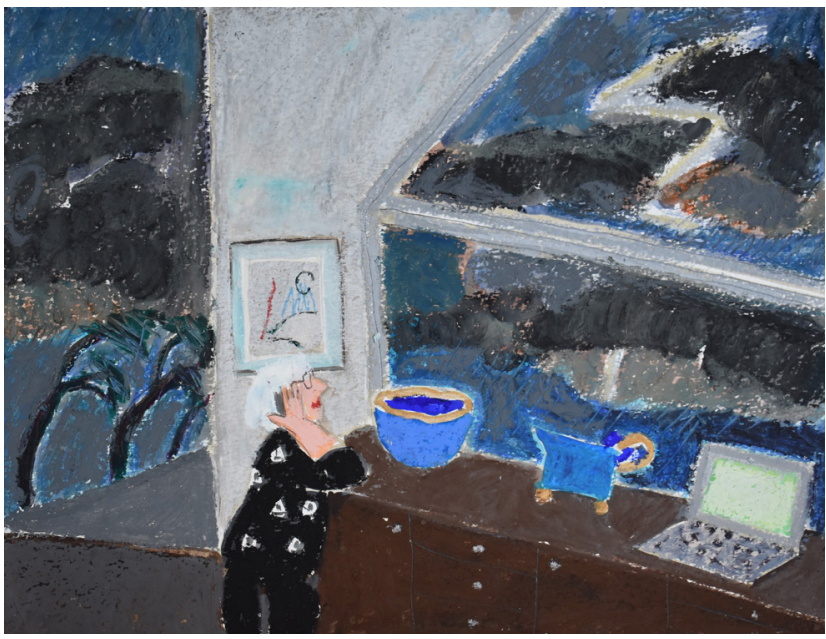

Ilustracja 11

Dziennik malarski, 2017:

Czasem pogoda konweniuje z trudna rozmowq (z mężem)

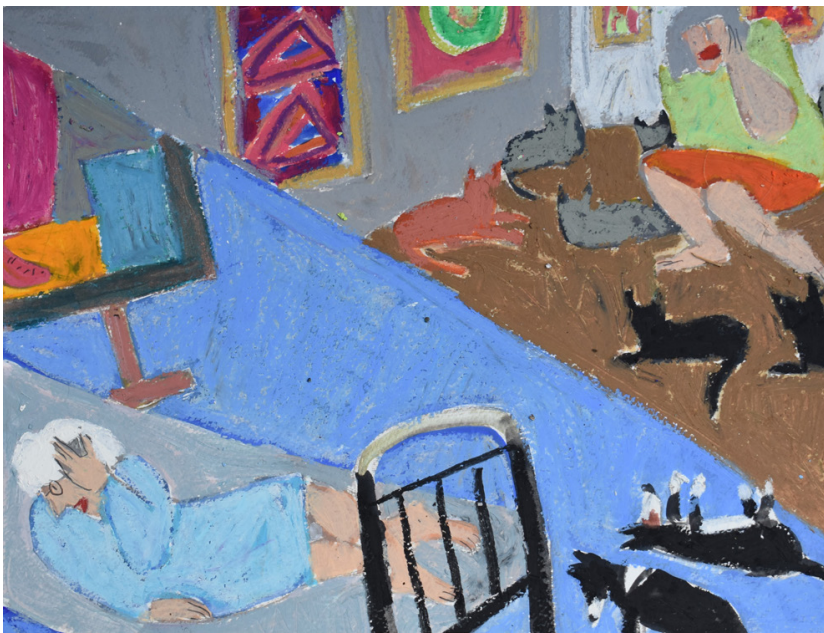

Ilustracja 12

Dziennik malarski, 2017:

Sa dni, w których tylko kolor daje

satysfakcje

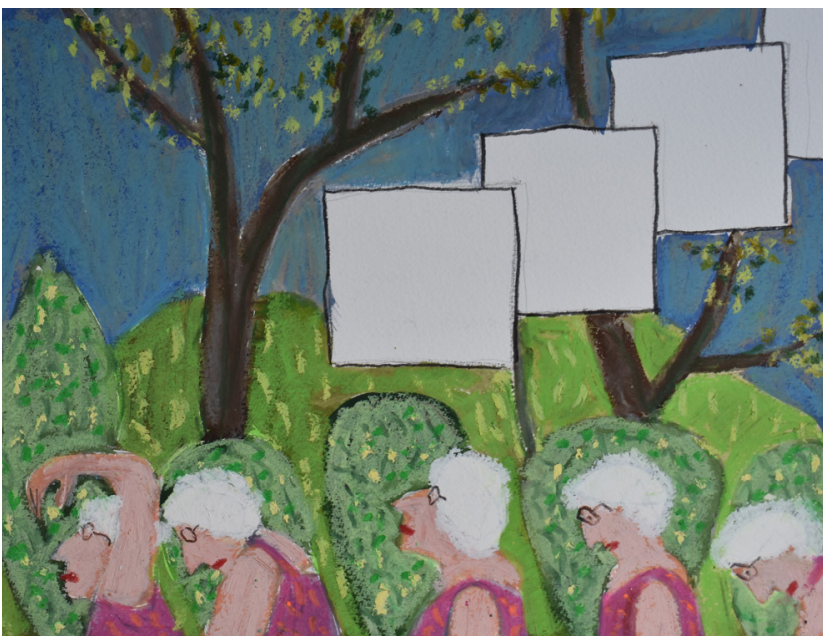

Ilustracja 13

Dziennik malarski, 2016:

Nagle powstaje ochota na

namalowanie cyklu kwadratowych

obrazów 


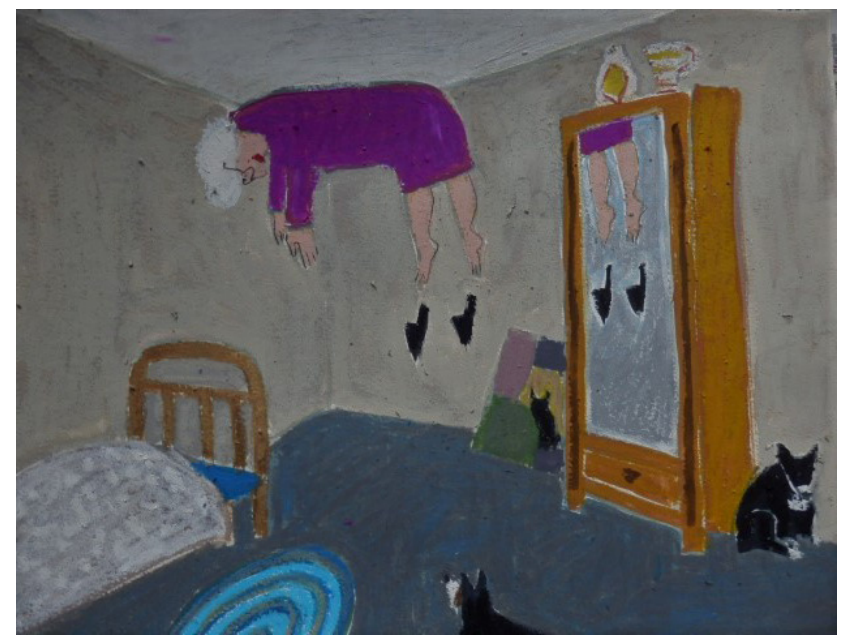

Ilustracja 14

Dziennik malarski, 2017:

Najważniejsze zachować dystans

Weronika Naszarkowska-Multanowska, obrazy

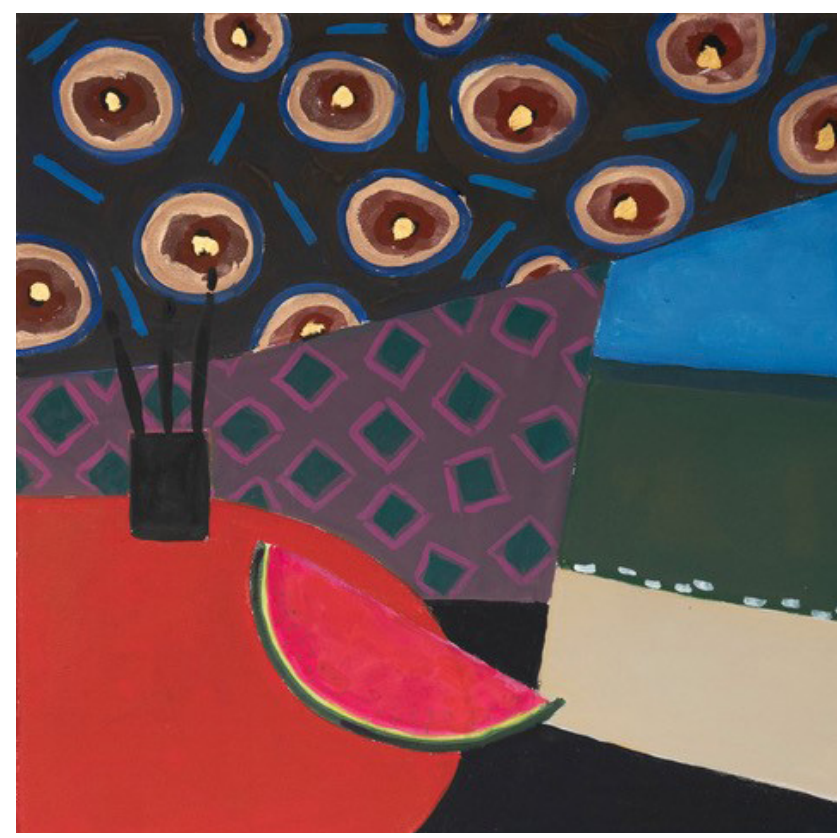

Ilustracja 15

Martwa natura z arbuzem, gwasz na płótnie $50 \times 50 \mathrm{~cm}, 2017$, fot. KN 


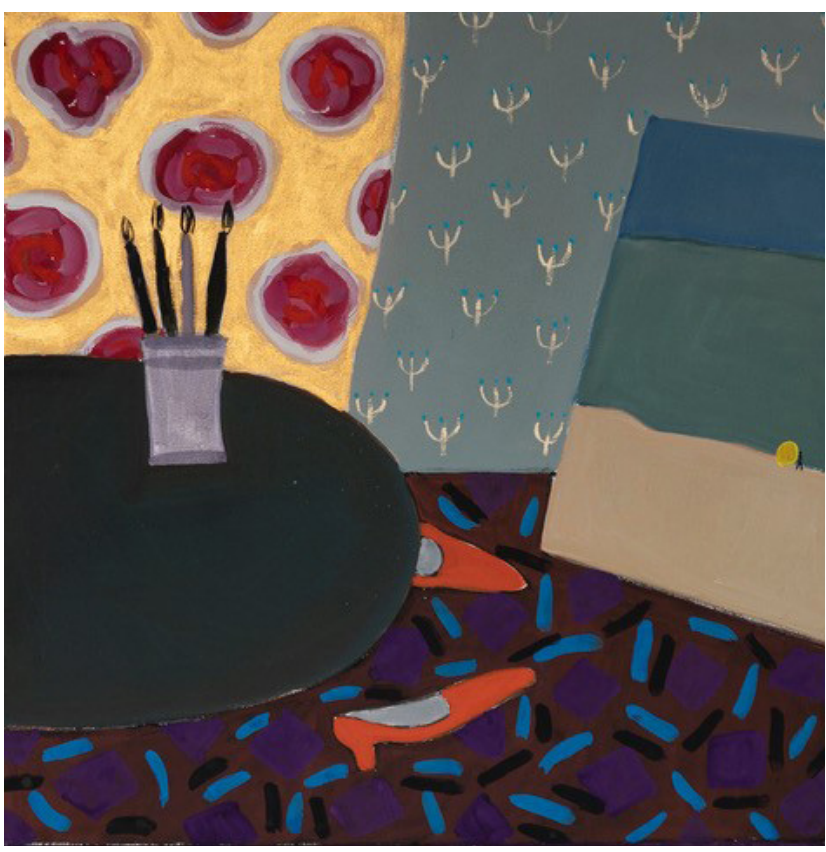

Ilustracja 16

Czerwone pantofle,

gwasz na płótnie

$50 \times 50 \mathrm{~cm}, 2017$, fot. KN

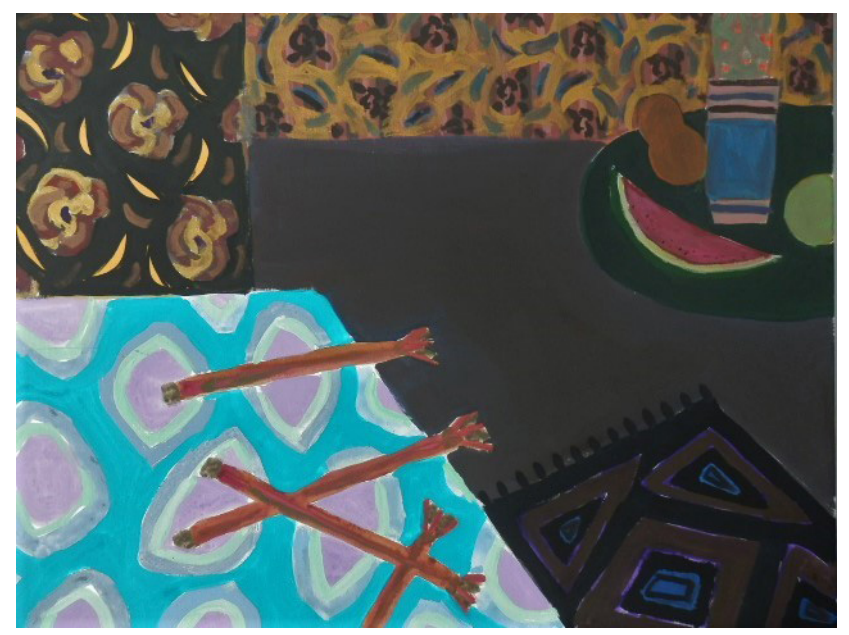

Ilustracja 17

Rabarbarowy / Ching, gwasz na płótnie

$50 \times 60 \mathrm{~cm}, 2017$, fot. KN 